\title{
Growing a Creative Preneure Through the Living Museum at Vocational School of PPN Lembang
}

\author{
Dimas Rachmat Susilo ${ }^{1, *}$ Nana Supriatna ${ }^{2}$ Yuver Kusnoto ${ }^{3}$ \\ ${ }^{1}$ History Education, School of Postgraduate Studies, Universitas Pendidikan Indonesia \\ ${ }^{2}$ History Education, School of Postgraduate Studies, Universitas Pendidikan Indonesia \\ ${ }^{3}$ History Education, School of Postgraduate Studies, Universitas Pendidikan Indonesia \\ *Corresponding author. Email: dimasrachmat66@gmail.com
}

\begin{abstract}
Problems that occur in SMK PPN Lembang. as a result of students' lack of understanding of historical awareness in the surrounding environment even though the role of history is closely correlated with historical agriculture. The lack of hours of history subjects at the SMK level makes it difficult for teachers to step into many things in connecting a material because it is required to complete learning. Given the urgency of implementing history subjects as an educative-constructive process, there needs to be a creative learning innovation. The focus of article writing introduces the concept of living museum as a solution idea in increasing the capability of students to innovate to produce quality agricultural products and have economic value. The research approach used is qualitative with research subjects all students of class X SMK PPN Lembang. The data collected in this article through observation, literature study, and interviews. The results show that students have understood the concept of living museum marked by the growth of the entrepreneurial spirit in each individual who is productive in producing agro-industrial products. Moreover, SMK PPN Lembang facilitates students to market their products by establishing a cafe called Gloriosis Kafe so that students are more enthusiastic in doing business in agriculture according to their expertise. The results show that students have understood the concept of living museum marked by the growth of the entrepreneurial spirit in each individual who is productive in producing agro-industrial products. Moreover, SMK PPN Lembang facilitates students to market their products by establishing a cafe called Gloriosis Kafe so that students are more enthusiastic in doing business in agriculture according to their expertise. The results show that students have understood the concept of living museum marked by the growth of the entrepreneurial spirit in each individual who is productive in producing agro-industrial products. Moreover, SMK PPN Lembang facilitates students to market their products by establishing a cafe called Gloriosis Kafe so that students are more enthusiastic in doing business in agriculture according to their expertise.
\end{abstract}

Keywords: Living Museum, Agriculture, History Learning. 


\section{INTRODUCTION}

Everyone already knows that our country, Indonesia, apart from being known as a maritime country, is also known as an agrarian country where many people earn a living as farmers who work in rice fields, fields, or gardens. As in Morris's book Bringing History to Life (5, p. 10) we have heard a home story as a shepherd telling about Christmas or we have visited the Plymouth fields of a historic farm or a historical site such as the Conner Praire farm to shed light on the past. past. Indonesia, which in fact depends a lot on farming, has become a developing country. Farmers are defined as work by utilizing natural resources to produce food, industrial materials or energy sources,

Agriculture is the activity of utilizing biological resources by humans to produce foo industrial raw materials, or energy sources, as well as to manage their environment (10, p. 225). Activities to empower natural resources including agriculture are usually understood as growing plants and raising livestock, although the scope can also be in the form of utilizing microorganisms and biological enzymes to process further products, for example the production of yogurt, bread, nata de coco, sake or simply extracting them. Most of the world's population lives from agriculture, but agriculture accounts for only $4 \%$ of world income.

Indonesia's history from the colonial period to the present is inseparable from plantations and agriculture because these fields are very important in ensuring the formation of various social and economic foundations in the territory of Indonesia. This is in line with the book Ecopedagogy by Nana Supriatna $(7$, p. 107) explaining learning from the concept of change from the past, the relationship between humans and the natural environment produces creative actions in the form of technological innovations to support human life. The agricultural sciences group studies agriculture with the support of the supporting sciences. Because agriculture is always limited by space and time, agriculture also studies supporting sciences such as climatology, geophysics, statistics, meteorology, biochemistry, and. soil.

The Ministry of Agriculture is ready to nurture young agricultural entrepreneurs over the next three years by providing business funding to agricultural students and agricultural graduates from agricultural universities and colleges. Dadih Permana, Head of the Department of Agriculture, Development and Agricultural Talent Distribution (BPPSDMP) said his party wanted to encourage the younger generation to become agricultural interpreters, or encourage young entrepreneurs to enter the business world with the PWMP Program for the Growth of Young
Agricultural Entrepreneurs (1). PWMP was launched in 2015 with the aim of generating interest in the younger generation towards technology and entrepreneurship in agriculture.

The concept of the Living Museum according to the book The Modern Living Museum: Some Reflections and Experiences (11, p. 47) explains that, the Museum must provide programs that are more interesting, educational, creative, and have a cultural identity where personal involvement is prioritized, learning together with "first hand". Not only exhibitions or exhibitions, but also explanations of the characters, functions and how to use them directly so that the purpose and meaning of the museum can be better understood.

With the concept of a living museum where the surrounding environment and daily socio-cultural life, become an inseparable part of the existence of the museum, it is closely related to learning history. learning history in class borrowing the concept students can relate to the environment in which they live is a place of learning as well as a source of learning for them in this case agriculture, such as examples of coffee and tea plantations that have existed since ancient times whose plantations are around students.

In the book Creative Pedagogy by Prof. Nana explains that a creative teacher must also be owned by a History and Social Science teacher in carrying out learning to accommodate all the wishes of children in one class through imaginative thinking in order to produce creative work. Teachers' imaginations about how to produce students' learning potential so that they have creative competencies will lead them to their future $(9$, p. 8$)$.

\section{RESEARCH METHOD}

The research method used in this study is a qualitative approach. Qualitative research basically observes people in their environment, relates to them and tries to understand the discussion and interpret the world around them (6, p. 5). Meanwhile, according to Dezin and Lincoln in Moleong $(4$, p. 5), qualitative research is research that uses a scientific context in order to explain phenomena that occur and is carried out using various methods.

Meanwhile, Nasution (6, p. 18) describes qualitative research as natural research because of the nature of the data collected through descriptions without using measuring tools. It is called naturalistic, because the situation in the research field is natural or natural as it is without being manipulated. Research conducted by researchers comes from a natural setting, namely the actual situation to uncover a phenomenon, not an experiment created by the researcher so that research 
that is suitable for use by researchers is qualitative research or naturalistic inquiry.

\section{DISCUSSION}

The main problem is the low interest in students' learning towards history learning which affects the level of historical awareness which is lacking coupled with several school facilities that do not support the learning process, such as the use of infocus which must take turns plus historical hours which are at least at the SMK level because they are only in class X Teachers who can be said to be at the forefront must be able to create creative things in learning. The implementation or ongoing learning or learning process that is creative and innovative depends on the imaginative ability of the teacher in designing learning and implementing it $(9$, p. 9$)$.

Learning methods that are active from both directions do not focus on the teacher as the only source, learning media that can attract students' interest in learning history, and other things that can increase students' enthusiasm for learning history. If limited learning resources are the reason for the teacher in existing problems, but usually from these limitations new creative ideas often emerge in solving a problem. As explained in Dasgupta's book (3, p. vii) creative culture is displayed in all the ways associated with the word "creativity" in material form as art objects, tools, weapons, machines, structures, books, textiles, and so on: and in symbolic or abstract form as a theory, theorem, law, plan, design, doctrine, idea, concept, procedure, algorithm, and others. One of them is by using the living museum concept, the living museum concept which is "as a reference for the establishment and management of museums in the future, where the surrounding environment and daily socio-cultural life become an inseparable part of the existence of this museum (2, p. 166).

Described in the journal Prof. Nana Supriatna $(9$, p. 77$)$ that "The choice of material can be flexible according to needs, including contextual issues. Current issues regarding the presidential election, the development of false information (hoaxes) in the internet world, national issues, the emergence of a consumer society related to students are connected topics". From this explanation that in history learning the teacher is not only fixated on the material in the book but the teacher must also be able to connect the material being taught with current issues so that learning becomes more interesting according to the times faced by students.

Currently the students of the Lembang State Agricultural Development Vocational School with the number of students only reaching 180 students, for the 2 (two) existing expertise competencies, it is very difficult to major in Agriculture, be it Horticultural Food Crops Agribusiness (ATPH) or Agricultural Product Processing Agribusiness (APHP). ) is a very popular major. Through these two majors, students are expected to be able to apply their knowledge gained at school into their daily lives, they not only get agricultural knowledge from productive subjects but also get other knowledge, for example from history subjects because there are several chapters that discuss about agricultural or environmental synergies with their expertise.

There should be awareness from students about the importance of history subjects at school because they not only discuss the past but they can also learn about the development of agriculture from the past to the present. Of course this must also be supported by the history teacher at school, the teacher does not only teach the transfer of material, the teacher must also be able to link the past and the present, especially in the field of agriculture which is called a creative teacher.

Take, for example, material on the history of Indonesia from the Pre-literate era, which discusses food gathering and food producing, what is it? Preliterate humans in the Paleolithic era obtained food by hunting and gathering food by collecting directly from nature (food gathering) and the Neolithic era or the young stone age was a revolution in the life of pre-literate humans. This is related to their thinking not to depend on nature and start trying to produce their own food (food producing) by farming.

The connection with the Agricultural Vocational School is that the lessons that students learn at school have also been experienced by early humans that it is not much different from what they do at school. Students should take a good thing from this material that those who farm and conduct food gathering and food producing live much healthier lives because they eat food from nature who already know very well how they grow it without using chemical fertilizers until harvesting it to be eaten directly or sold to the dealers. vegetables as well as supermarkets around Lembang. Such a statement is supported by Prof. Nana Supriatna in her book Ecopedagogy (7, p. 215) says "Some of the reasons consumers choose organic products, namely; chemical free; More nutrients (plants grown organically are rich in nutrients, minerals, micronutrients and enzymes, than conventional plants); tastes better (high nutritional content makes organic vegetables or fruits taste better; and preserves the environment and reduces pollution. Organic products are environmentally friendly because they do not use chemical fertilizers and pesticides, and are free of genetic engineering and antibiotics". 
Students should take a good thing from this material that those who farm and conduct food gathering and food producing live much healthier lives because they eat food from nature who already know very well how they grow it without using chemical fertilizers until harvesting it to be eaten directly or sold to the dealers. vegetables as well as supermarkets around Lembang. The use of agricultural machinery in SMK is closely related to the history of the first industrial revolution in England. In the past, agricultural equipment was very limited, causing agricultural yields to be minimal. By using increasingly sophisticated machines, ATPH children can increase agricultural yields to increase income. Studying the history of the material The entry of Colonialism and Imperialism into Indonesia, was caused by the spices of the Archipelago.

For the APHP department at the PPN Lembang Vocational School, this matter does focus on processing agricultural products based on modern technology. Maybe you have thought that the APHP major is also somewhat similar to the Catering Department in the same way that it processes food ingredients. But there is a stark difference, namely that the Department of Catering, food ingredients that have been processed will be served and beautified, while APHP, processed foodstuffs will be packaged immediately so that the level of product resilience and durability must be considered. Here students will also be taught entrepreneurship, by utilizing the potential of local agricultural products, especially Lembang. Students are taught how to create agricultural materials into unique products so that they have a high selling value and there are many other knowledges gained in this department. According to researchers, this major is important. Because, with Indonesia's agrarian environment so that it has abundant agricultural potential, it will be a shame if it is not used as a high selling value product. But unfortunately this department is still empty of enthusiasts and is often underestimated because of the lack of knowledge of ordinary people about this department. So do not underestimate this department with the many benefits that are in it.

History teachers can relate this department to history learning, for example from the results of a superior product, namely coffee with the brand name Coffehape as explained by previous researchers in the background of this thesis. This coffee is closely related to Indonesian history subjects, especially in Sundaland, teachers must be able to connect their coffee products with how the early history of coffee got here. Prof. Nana Supriatna in her book Prose from Prague explains that (8, p. 320) "The coffee cultivation program in Priangan was implemented a century earlier than Forced Cultivation (1830-1870).
Forced Cultivation in Priangan was what inspired Daendels (1808-1811) to then enforce it throughout Java. The forced cultivation of coffee in Priangan is the most profitable forced cultivation in history."

The same thing is still confirmed in Prof. Nana's work in the book Creative Pedagogy which explains that developing historical material must be close to students and contemporary with their lives is a good approach to foster creativity. Creativity in terms of entrepreneurship appears in how to find innovation opportunities in community economic activities which are recorded as historical facts $(9, \mathrm{p}$. 110).

The coffee that is processed in this school is a natural product because in its processing it does not use any additional preservatives without exception because they are aware of the importance of consuming natural products, processed coffee is not only sold to the public but also sold in the school environment as one of the natural artificial products that are naturally produced. sold at the Gloriosis Cafe, which is a school-choice cafe along with other natural and healthy snacks that are processed by students' products, they don't just snack on chemicals that are now often found around, children now tend to prefer snacks that are processed by factories with lots of chemicals, even though we know the product is clearly not healthy especially if consumed continuously will cause digestive cancer.

Prof. Nana Supriatna in the book Ecopedagogy explains (7, p. 300) "A careful and intelligent attitude is needed, especially for school children in choosing healthy snacks. This is important and must be instilled by parents and teachers to students in growing an understanding of the importance of choosing healthy snacks. Education is expected to build an understanding of sustainable life about ecological intelligence, one of which is to foster green behavior and emotional bonds with nature".

\section{CONCLUSION}

Creative history learning will make students become active when. Today's history teachers must be able to get rid of the negative stigma about subjects that are boring and just fairy tales. Though there are many ways that can be done so that learning history becomes fun. Limitations of learning resources or other obstacles should not be used as an excuse not to think creatively. One of them is the concept of a living museum where the surrounding environment becomes a source and place for learning which includes the socio-cultural life of the surrounding community. In this case, life in Lembang, where the majority of the people rely on agriculture for their livelihood. Linking historical 
material with agriculture is very relevant, coupled with borrowing the concept of a living museum, This will make historical learning creative that is contemporary because it is directly related to the daily life of students and their parents. Will create a sense of love for history.

The Living Museum makes students learn to know their environment and makes them think by utilizing agricultural products into something new that has economic value. Studying this, the final result to be achieved is the birth of creative preneur souls in agriculture. The Living Museum makes students learn to know their environment and makes them think by utilizing agricultural products into something new that has economic value. Studying this, the final result to be achieved is the birth of creative preneur souls in agriculture. The Living Museum makes students learn to know their environment and makes them think by utilizing agricultural products into something new that has economic value. Studying this, the final result to be achieved is the birth of creative preneur souls in agriculture.

\section{AUTHORS' CONTRIBUTIONS}

In this article all authors collect data without collection. Dimas Rachmat Susilo designs, analyzes and writes articles. Nana Supriatna analyzed and revised the article. Yuver Kusnoto did the analysis. After all the steps have been done scientifically, we next record the final results, so everyone joins the work in this.

\section{ACKNOWLEDGMENTS}

Thank you to the Graduate School of History Education Study Program, Universitas Pendidikan Indonesia for the opportunity and support so that this article can be published. And to all related parties who I cannot mention one by one here due to limited writing space in including them.

\section{REFERENCES}

[1] Anonim. (2018). Kementan Siap Bantu Modal Wirausahawan Muda Pertanian. Tersedia. [Online]:

http://www.pertanian.go.id/home/?show=news\&a ct=view\&id=1767 (diakses 26 Maret 2021 pukul 22.14 WIB)

[2] Couteau, Jean \& Warih Wisatsana. (2013). Gung Rai: Kisah Sebuah Museum. Jakarta: Kepustakaan Populer Gramedia

[3] Dasgupta, Subrata. (2019). A Cognitive Historical Approach to Creativity. New York: Routledge
[4] Moleong, L. J. (2017). Metode Penelitian Kualitatif. Bandung: PT Remaja Rosdakarya Offset

[5] Morris, Vaughan Ronald. (2009). Bringing History to Life. Maryland: The Rowman \& Littlefield Publishing Group, Inc

[6] Nasution, S. (1992). Metode Penelitian Naturalistik Kualitatif. Bandung: Tarsito

[7] Supriatna, Nana. (2017). Ecopedagogy. Bandung: PT Remaja Rosdakarya

[8] Supriatna, Nana. (2018). Prosa dari Praha. Bandung: PT Remaja Rosdakarya

[9] Supriatna, Nana dan Neni Maulidah. (2020). Pedagogi Kreatif: Menumbuhkan Kreativitas dalam Pembelajaran Sejarah dan IPS. Bandung: PT Remaja Rosdakarya

[10] Ryand. (1999). Safety and Health in Agriculture. International Labour Organization

[11] UNESCO. (1975). The Modern Living Museum: Some Reflections and Experiences. Lausanne: Presses Centrales S. 